\title{
Intracellular chemiluminescence activates targeted photodynamic destruction of leukaemic cells
}

\author{
R Laptev', M Nisnevitch', G Siboni ${ }^{2}$, Z Malik ${ }^{2}$ and MA Firer ${ }^{*, 1}$ \\ 'Department of Chemical Engineering and Biotechnology, College of Judea and Samaria, Ariel 44837, Israel; ${ }^{2}$ Faculty of Life Sciences, Bar-llan University, \\ Ramat-Gan, Israel
}

Photodynamic therapy (PDT) involves a two-stage process. A light-absorbing photosensitiser (Ps) is endocytosed and then stimulated by light, inducing transfer of energy to a cytoplasmic acceptor molecule and the generation of reactive oxygen species that initiate damage to cellular membrane components and cytolysis. The expanded use of PDT in the clinic is hindered by the lack of Ps targetcell specificity and the limited tissue penetration by external light radiation. This study demonstrates that bioconjugates composed of transferrin and haematoporphyrin ( $\mathrm{Tf}-\mathrm{Hp}$ ), significantly improve the specificity and efficiency of PDT for erythroleukemic cells by a factor of almost seven-fold. Fluorescence microscopy showed that the conjugates accumulate in intracellular vesicles whereas free $\mathrm{Hp}$ was mostly membrane bound. Experiments with cells deliberately exposed to Tf-Hp at $<L_{1} D_{100}$ doses showed that surviving cells did not develop resistance to subsequent treatments with the conjugate. Furthermore, we show that the compound luminol induces intracellular chemiluminescence. This strategy was then used to obviate the use of external radiation for Ps activation by incubating the cells with luminol either before or together with Tf-Hp. This novel chemical means of PDT activation induced cytotoxicity in 95\% of cells. These combined approaches provide an opportunity to develop broader and more effective applications of PDT. British Journal of Cancer (2006) 95, 189-196. doi: 10.1038/sj.bjc.660324I www.bjcancer.com

Published online 4 July 2006

(c) 2006 Cancer Research UK

Keywords: targeted drug delivery; photodynamic therapy; transferrin; luminol; intracellular activation

The nonselectivity of chemotherapeutic agents has stimulated development of targeted drug delivery strategies such as ligand toxin conjugates (LTCs), involving the coupling of an effector molecule to a transport ligand of a target cell-specific receptor (Rihova, 1998; Mrsny, 2004). Smaller ligands such as peptides or other small molecules may have advantages over larger molecules like antibodies (Rihova, 1998; Shadidi and Sioud, 2003). We recently reported on the use of small molecule-containing LTCs for the targeted destruction of plasma cells (Firer et al, 2003) suggesting that this approach may be applicable for multiple myeloma therapy. The LTC strategy for targeting tumour cells represents one focus of the present study.

The second focus involves photodynamic therapy (PDT), a twostage procedure based on two nontoxic components that combine to induce membrane alterations leading to cytolysis. The first component is a photosensitiser (Ps) molecule, usually a porphyrin derivative, that when light-activated transfers energy to molecular oxygen, producing reactive oxygen species that cause direct damage to cellular components, particularly membrane phospholipids. Photodynamic therapy is believed to mediate tumour cell destruction by at least two additional mechanisms: destruction of tumour vascular cells and the induction of both inflammatory and immune antitumour reactions (Dougherty et al, 1998; van Duijnhoven et al, 2003). The history, mechanism of action and biomedical applications of PDT have been the subject of several

*Correspondence: Dr MA Firer;

E-mail: firer@research.yosh.ac.il

Revised 5 June 2006; accepted 6 June 2006; published online 4 July 2006 comprehensive reviews (Ceburkov and Gollnick, 2000; Dolmans et al, 2003; Brown et al, 2004; Sharman et al, 2004).

Two major issues limit the wider application of PDT as a treatment modality. First, whereas Pss tend to accumulate in tumour tissue, their clinical use is often associated with side effects such as cutaneous photosensitivity (Vrouenraets et al, 2003; Sharman et al, 2004). To overcome this problem investigators have covalently linked the Ps to carrier molecules so as to localise the PDT effect (Klyashchitsky et al, 1994; Vrouenraets et al, 2003). One attractive carrier protein-receptor system for this purpose utilises the high-affinity interaction between the iron-transporter transferrin (Tf) and its cell-surface receptor (TfR, CD71). As all dividing cells require a continuous supply of iron for metabolism, it is not surprising that $\mathrm{TfR}$ is overexpressed on a variety of malignant cells (Ponka et al, 1998), so the Tf-TfR system has been used in several formats to target Ps compounds to different types of malignant cells (Hamblin and Newman, 1994; Rittenhouse-Diakun et al, 1995; Cavanaugh, 2002; Gijsens et al, 2002; Li and Qian, 2002). The second major issue regarding PDT is the limited tissue penetration of external laser light. Despite advances in the development of external light devices for phototherapy (Brancaleon and Moseley, 2002) and the successful clinical use of PDT for peripheral cancers (Stockfleth and Sterry, 2002; Dolmans et al, 2003; Moan and Peng, 2003; Brown et al, 2004) and in dermatology (Ceburkov and Gollnick, 2000), the treatment of internal body tissues remains limited to invasive procedures, such as the use of endoscopes. Although these procedures may involve acceptable discomfort to the patient compared to other treatments such as surgery, there are only isolated reports of attempts to develop molecular approaches to Ps activation. These studies used chemiluminescence (CL), in 
190

which the in situ conversion of molecular oxygen to superoxide ions and the subsequent release of light energy achieved is without electrical input or thermal output. Carpenter et al (1994) employed intracellular bioluminescent activation of hypericin and the subsequent destruction of equine dermal cells, whereas Phillip and Maximuke (1989) used a haematoporphyrin derivative (Photofrin II) and a multicomponent solution to induce intracellular CL in mammary adenocarcinomas. In searching for a simple means to induce intracellular CL, we turned to luminol, which has been successfully used in a variety of CL-based assays systems (Kricka, 2002). The mechanism of the CL reaction of luminol has been known for some time (White et al, 1964) and whereas some physico-chemical aspects of luminol activation in macrophages have been examined (Nemeth et al, 1999), the luminol-PDT connection has never been exploited to induce PDT cytotoxicity in tumour cells.

The present study combines these new approaches to overcome the above-mentioned limitations to PDT applications. We first demonstrate the efficacy of the targeted LTC strategy using the transferrin and haematoporphyrin (Tf-Hp) system. We then establish in vitro proof of principle that luminol can be used as a powerful molecular inducer of intracellular CL for the destruction of leukemic cells, overcoming the need of external light sources in PDT.

\section{MATERIALS AND METHODS}

Hp, rabbit anti-human transferrin, goat anti-bovine serum albumin (BSA), transferrin, $N$-hydroxysuccinimide and luminol (5-amino-2-3-dihydro-1, 4-phtalazinedione) were purchased from Sigma-Aldrich Chemical Co., Rehovot, Israel, $N, N$-dicyclohexyl carbodiimide (DCC) and tetrahydrofuran were from Carlo Erba, Radona, Italy. Horse serum (HS), fetal calf serum, Dulbecco's modified Eagle's medium (DMEM), RPMI, L-glutamine and combined antibiotics were purchased from Biological Industries Ltd (Bet Haemek, Israel). High-pressure liquid chromatography (HPLC) solvents were from Merck, Rosh Haayin, Israel.

\section{Cells}

U7.6 is a murine hybridoma that secretes IgG1 antibody against dinitrophenol and was a kind gift of Professor Eshhar (Weizmann Institute of Science, Rehovot, Israel). These cells as well as Friend's leukaemia (FL) cells were grown in DMEM containing 15\% HS, $2 \mathrm{mM}$ L-glutamine and combined antibiotics. Human K-562 cells were grown in RPMI/15\% HS/glutamine/antibiotics. All cells were maintained at $37^{\circ} \mathrm{C}$ in a humidified incubator containing $6 \% \mathrm{CO}_{2}$ and were passaged every 3-4 days. For the experiments described here, cells were grown from a single frozen vial of each cell type.

\section{Preparation of Hp containing LTCs}

Haematoporphyrin hydrochloride $(0.11 \mathrm{mmol})$ was dissolved in $10 \mathrm{ml}$ chloroform and activated by addition of $0.173 \mathrm{mmol}$ of $\mathrm{N}$-hydroxysuccinimide and $0.11 \mathrm{mmol}$ DCC. The mixture was stirred at room temperature for $2.5 \mathrm{~h}$. Following evaporation with a stream of air, the residue was dissolved in $2 \mathrm{ml}$ of tetrahydrofuran (THF) and the activated $\mathrm{Hp}$ was slowly added to a solution of $15 \mathrm{mg}$ transferrin dissolved in $10 \mathrm{ml}$ of $0.1 \mathrm{M} \mathrm{NaHCO}_{3}$ cooled on ice. The solution was allowed to warm to room temperature, adjusted to $\mathrm{pH} 7.5$ and stirred vigorously overnight. Tubes containing $\mathrm{Hp}$ were protected from light exposure. The conjugate solution was centrifuged $\left(7200 \mathrm{~g}, 30 \mathrm{~min}, 4^{\circ} \mathrm{C}\right)$ and the supernatant was analysed spectroscopically for the content of protein $(\lambda=280 \mathrm{~nm})$ and $\mathrm{Hp}(\lambda=400 \mathrm{~nm})$. After dialysis, a small portion of the crude reaction product was chromatographed over Sephadex G-50 equilibrated with $5 \mathrm{~mm} \mathrm{NaHCO}_{3}(\mathrm{pH} \quad 8.0)$ or $10 \mathrm{~mm}$ phosphate-buffered saline (PBS) (pH 7.2). Fractions containing materials with absorption peaks at 280 and $400 \mathrm{~nm}$ were collected and stored at $4{ }^{\circ} \mathrm{C}$.

\section{Characterisation of the $\mathrm{Tf}-\mathrm{Hp}$ conjugate}

High-pressure liquid chromatography $\mathrm{Tf}, \mathrm{Hp}$ and $\mathrm{Tf}-\mathrm{Hp}$ were chromatographed over a C-18 column $(3.9 \times 300 \mathrm{~mm}$ Bondclone, particle diameter $10 \mu \mathrm{m}$, Phenomenex, Torrance, CA, USA) using a HPLC JASCO-1580 with a JASCO 1575 UV/VIS detector set at $280 \mathrm{~nm}$. The solvent system was composed of acetonitrile-water with $1 \%$ trifluoroacetic acid and compounds were eluted with a linear gradient $(20-100 \%$ acetonitrile).

Absorbance spectrum The absorbance spectra of PBS solutions of $\mathrm{Hp}\left(0.02 \mathrm{mg} \mathrm{ml}^{-1}\right)$, Tf $\left(1.4 \mathrm{mg} \mathrm{ml}^{-1}\right)$ and $\mathrm{Hp}-\mathrm{Tf}\left(1.4 \mathrm{mg} \mathrm{ml}^{-1}\right)$ were recorded with a CHEMUSB2-UV-VIS spectrophotometer having optical resolution of $1 \mathrm{~nm}$, grating of 600 lines $\mathrm{mm}^{-1}$ equipped with CCD array detector. The samples were scanned in the absorbance region of $250-500 \mathrm{~nm}$.

Biological activity This was assessed by the ability of antitransferrin or anti-BSA antibodies to inhibit PDT-induced cytotoxicity. Friend's leukaemia cells were cultured with $3 \mu \mathrm{M} \mathrm{Tf}-\mathrm{Hp}$ in the LTC cytotoxicity assay (see below) together with $0-200 \mu \mathrm{g} \mathrm{ml}^{-1}$ of each antibody.

\section{Ligand toxin conjugate cytotoxicity assay}

Late log-phase cells were washed with DMEM prewarmed to $37^{\circ} \mathrm{C}$ and cultured at $0.5-1 \times 10^{5}$ cells ml $^{-1}$ either alone or with increasing concentrations of Tf-Hp LTC for $2 \mathrm{~h}$ at $37^{\circ} \mathrm{C}$ in $6 \%$ $\mathrm{CO}_{2}$. Cells were then washed with DMEM, exposed to white fluorescent light (fluence rate $=0.5 \mathrm{~mW} \mathrm{~cm}^{-2}$ ) overnight, usually $16 \mathrm{~h}$ and then recultured in full medium for $24 \mathrm{~h}$. The emission spectrum covered the wavelengths $350-700 \mathrm{~nm}$. Cell viability was determined by trypan blue exclusion. Experiments were repeated at least three times. The optimal exposure times of cells to the Ps and fluorescent radiation were determined in preliminary time-course experiments (data not shown).

\section{Fluorescence microscopy of $\mathrm{Hp}$ and $\mathrm{Tf}-\mathrm{Hp}$ endocytosis}

Friend's leukaemia cells were grown on glass slides in tissue culture dishes together with $\mathrm{Hp}$ or $\mathrm{Tf}-\mathrm{Hp}$ and the incorporated fluorescence was followed at various time intervals with an AX70 Olympus microscope equipped with a high-pressure mercury lamp for excitation and a set of filters for blue violet excitation (band path 420-480 nm), dichroic mirror $(455 \mathrm{~nm})$ and a cut-on red emission barrier filter $(580 \mathrm{~nm})$. Fluorescence was analysed with an $60 \times$ objective, without addition of any antibleaching solution, and recorded by a CCD camera.

\section{Cellular uptake of $\mathrm{Tf}-\mathrm{Hp}$ conjugate}

To ascertain the kinetics of cellular uptake of the $\mathrm{Tf}-\mathrm{Hp}$ conjugate, $10^{6} \mathrm{ml}^{-1}$ FL cells were incubated at $37^{\circ} \mathrm{C}$ for $0,15,30,60$ or $120 \mathrm{~min}$ with $3 \mu \mathrm{g} \mathrm{ml}^{-1} \mathrm{Tf}-\mathrm{Hp}$. The cells were then washed three times with PBS and the fluorescence was measured by FACSCalibur (Beckon Dickinson, San Jose, CA, USA). Approximately $10^{4}$ cells were analysed in each sample. From the output data, the increase in mean fluorescence units per minute was calculated.

\section{Resistance to $\mathrm{Tf}-\mathrm{Hp}$ treatment}

To test the effect of repeated exposure to $\mathrm{Tf}-\mathrm{Hp}$, FL cells were treated with $\mathrm{Tf}-\mathrm{Hp}$ in the cytotoxicity assay as described above. Cells surviving treatment at the $\mathrm{LD}_{90}$ concentration were 
maintained in $\mathrm{Tf}-\mathrm{Hp}$-free culture medium until they regained pretreatment growth kinetics (approximately 3 weeks). These cells were designated 'Single treatment FL.' and together with previously untreated FL, were tested for their response to a range of LTC doses. Single-treatment FL cells surviving a second exposure at $\mathrm{LD}_{90}$ were in turn cultured and termed 'Double treatment FL.' This cycle was repeated to derive 'Triple treatment FL.'

\section{Measurement of intracellular CL induced by luminol}

To ascertain the ability of luminol to induce intracellular luminescence, we performed measurements using a fluorescence spectrometer (Varian Eclipse, Palo Alto, CA, USA) set at bio/CL mode. Stock solutions of $100 \mathrm{~mm}$ luminol in $10 \% \mathrm{NaOH}$ and $5 \mathrm{~mm}$ ferrous sulphate and LB buffer $(0.14 \mathrm{M} \mathrm{NaCl}, 0.027 \mathrm{M} \mathrm{KCl}, 0.012 \mathrm{M}$ $\mathrm{Na}_{2} \mathrm{HPO}_{4} .2 \mathrm{H}_{2} \mathrm{O}, 0.015 \mathrm{M} \mathrm{K}_{2} \mathrm{PO}_{4}, 0.9 \mathrm{mM} \mathrm{CaCl}_{2}, 0.5 \mathrm{~mm} \mathrm{MgCl}_{2} .6 \mathrm{H}_{2} 0$, $\mathrm{pH}=7.6$, Kawagoe and Nakagawa, 2000) were prepared. A mixture of $1 \mathrm{~mm}$ luminol, $1 \mathrm{~mm}$ iron catalyst and $1 \% \mathrm{H}_{2} \mathrm{O}_{2}$ was also prepared and used to calibrate the system. Then to measure the influence of luminol on cellular luminescence, log-phase FL cells were collected, washed twice in LB buffer, resuspended at $10^{5}$ or $10^{6}$ viable cells $\mathrm{ml}^{-1}$ in LB buffer $+1 \mathrm{~mm}$ iron catalyst alone or together with $1 \mathrm{~mm}$ luminol. The cell suspensions were monitored for CL for up $50 \mathrm{~min}$.

\section{Intracellular PDT activation by luminol}

In initial experiments, FL cells were washed and cultured for $20 \mathrm{~h}$ with different concentrations of $\mathrm{Hp}$ or $\mathrm{Tf}-\mathrm{Hp}(0.07,0.15$ or $0.3 \mu \mathrm{M})$ together with luminol $(0-10 \mu \mathrm{M})$. All manipulations of cells and components were performed with the room lights switched off. Culture plates were wrapped in aluminium foil during the culture period. Subsequent experiments aimed to test whether a PDT effect could be obtained by staggering the exposure of the cells to either luminol or $\mathrm{Tf}-\mathrm{Hp}$ conjugate. In one series, FL cells were cultured for $2 \mathrm{~h}$ in the dark at $37^{\circ} \mathrm{C}$ with $\mathrm{Tf}-\mathrm{Hp}(3 \mu \mathrm{M})$, washed and resuspended in medium at the standard culture concentration. This procedure took approximately $15 \mathrm{~min}$. Then, the cells were kept at $37^{\circ} \mathrm{C}$ for an additional $0,30,60$ or $90 \mathrm{~min}$, luminol $(10 \mu \mathrm{M})$ was added and the cultures incubated in the dark for a further $16 \mathrm{~h}$. Alternatively, cells were first cultured for $24 \mathrm{~h}$ in the dark in the presence of $10 \mu \mathrm{m}$ luminol, washed or not-washed and then cultured further for $24 \mathrm{~h}$ in the presence of $\mathrm{Tf}-\mathrm{Hp}(0-3 \mu \mathrm{M})$ at $37^{\circ} \mathrm{C}$. During washing procedures and cell handling, special care was taken to maintain the cells in a dark environment.

\section{Statistical analysis}

Statistical analyses of the data were performed by two-way analysis of variance (ANOVA) (F-distribution) and least-squares regression.

\section{RESULTS}

\section{Purification and characterisation of the Tf-Hp conjugate}

The Tf-Hp conjugate was separated from Tf and Hp by HPLC and characterised by UV-Vis spectrophotometry (Figure 1). The Tf spectrum reveals a typical maximum at $\lambda=280 \mathrm{~nm}$, whereas $\mathrm{Hp}$ absorption maximum is at $\lambda=375 \mathrm{~nm}$. The $\mathrm{Hp}-\mathrm{Tf}$ conjugate revealed two absorption peaks at $\lambda=280$ and $412 \mathrm{~nm}$ and the spectrum is characterised by a red shift of the maximum and is not a simple superposition of the spectra of its components. The molar ratio of the two conjugates components was determined spectroscopically to be $6.3 \mathrm{Hp} / 1 \mathrm{Tf}$. The biological activity of the conjugate was verified by determining the ability of antibodies to interfere with LTC cytotoxicity. The addition of antitransferrin to assay cultures of FL cells reduced cytotoxicity by $50 \%$ at $100 \mu \mathrm{g} \mathrm{ml}^{-1}$

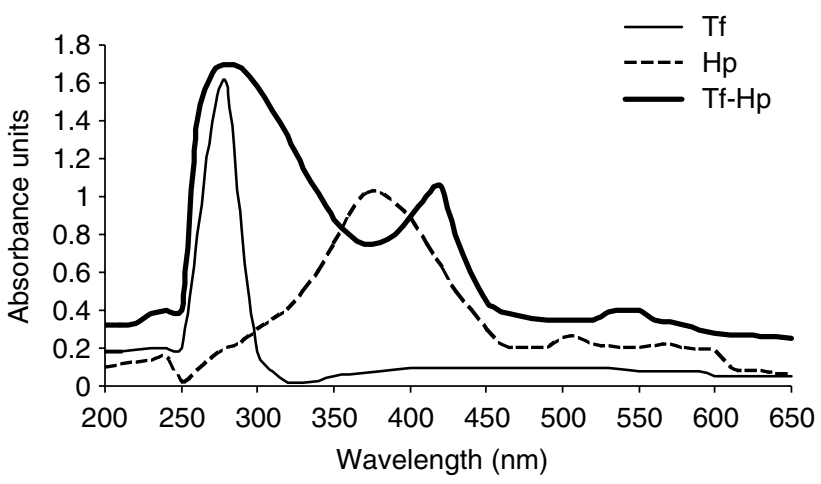

Figure I UV-VIS absorbance spectra in the interval of $250-500 \mathrm{~nm}$ for

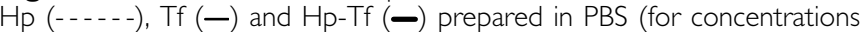
see Materials and Methods)

antibody and by $95 \%$ at $200 \mu \mathrm{g} \mathrm{ml}^{-1}$ antibody. The addition of anti-BSA to parallel cultures reduced cytotoxicity by 10 and $5 \%$, respectively.

\section{Direct cytotoxicity of Tf-Hp LTCs with external photoactivation}

Friend's leukaemia, K562 and U-76 cells were incubated with various concentrations of $\mathrm{Hp}$ or $\mathrm{Tf}-\mathrm{Hp}$ in the dark for $2 \mathrm{~h}$ and then exposed overnight exposure to white fluorescent light. Control cells kept under similar environmental conditions but not exposed to $\mathrm{Hp}$ or light showed $95 \%$ viability. Treatment with high concentrations of Tf-Hp alone induced low-level cytotoxicity (Figure 7). For all cell types, dose-response effect (Figure 2) of $\mathrm{Tf}-\mathrm{Hp}$ was significantly more cytotoxic than $\mathrm{Hp}$ alone (for FL $P=0.042$; for $\mathrm{K}-562 P=0.034$, for $\mathrm{U}-76 \mathrm{P}=0.038$ ). Table 1 shows that the concentration of $\mathrm{Tf}-\mathrm{Hp}$ required to achieve $\mathrm{LD}_{50}$ was more than six-fold lower than for $\mathrm{Hp}$. Furthermore $\mathrm{LD}_{100}$ values were only obtained with the Tf-Hp. U-76 hybridoma cells were relatively insensitive to PDT. The concentration of $\mathrm{Tf}-\mathrm{Hp}$ required to reach $\mathrm{LD}_{90}$ in these cells was $>19.4$-fold higher than for FL cells and >3.5-fold higher than for K-562 cells. This order of sensitivity was retained at the concentrations required for $\mathrm{LD}_{\mathrm{MAX}}$ (3.37 for FL and 0.8 for K562). Furthermore, $100 \%$ cytotoxicity was only obtained when the conjugate was used against the erythroleukemic cell lines. A similar pattern of sensitivity was also seen with free $\mathrm{Hp}$ treatment. Although a similar $(90 \%) \mathrm{LD}_{\mathrm{MAX}}$ was reached for both erythroleukemic lines, FL cells were 16.6 more sensitive than K-562.

Further evidence for the increased cytotoxicity of Tf-Hp over free $\mathrm{Hp}$ was obtained from fluorescence microscopy. Figure 3 illustrates the presence and location of the Ps in FL cells after 45 and 60 min incubation with either $\mathrm{Hp}$ (left panel) or Tf-Hp (right panel). At both time points, relatively faint (as no anti bleaching solution was used) $\mathrm{Hp}$ fluorescence was observed mainly constrained to the plasma membrane region. Significantly greater fluorescence was apparent in cells treated with Tf-Hp. After $45 \mathrm{~min}$, the conjugate localised in membrane patches (probably demarcating endolysosomal compartments) and had infiltrated much of the cytoplasm by $60 \mathrm{~min}$.

The characteristics of $\mathrm{Tf}-\mathrm{Hp}$ uptake kinetics in the FL were examined by incubating them with conjugate for various times and measuring the cell-associated fluorescence by fluorescence-activated cell sorting (FACS). Figure 4 shows that the uptake was linear over the $120 \mathrm{~min}$ of the experiments with an uptake rate of 0.056 arbitrary fluorescence units $\mathrm{min}^{-1}$.

\section{Resistance of FL cells to repeated Tf-Hp treatments}

We tested whether repeated exposure to $\mathrm{Tf}-\mathrm{Hp}$ may lead to the development of resistance in treated cells by adapting a protocol 
Table I Comparison of cytotoxic efficiency of PDT induced by Tf-Hp or $\mathrm{Hp}$ for three cell lines

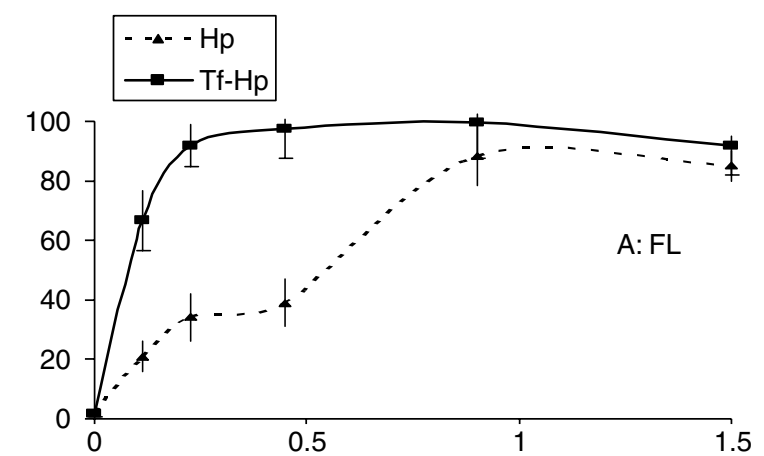

\begin{tabular}{|c|c|c|c|}
\hline \multirow[b]{2}{*}{ Parameter } & \multicolumn{3}{|c|}{ Cell type } \\
\hline & $\mathbf{F L}$ & K-562 & U-7.6 \\
\hline \multicolumn{4}{|c|}{ Concentration at $L D_{50}(\mu \mathrm{M})$} \\
\hline $\mathrm{Hp}$ & 0.55 & 1.9 & NR \\
\hline $\mathrm{Tf}-\mathrm{Hp}$ & 0.08 & 0.3 & 0.5 \\
\hline Ratio $^{\mathrm{a}}$ & 6.88 & 6.33 & - \\
\hline \multicolumn{4}{|c|}{ Concentration at $L D_{90}(\mu \mathrm{M})$} \\
\hline $\mathrm{Hp}$ & NR & 7.5 & $N R$ \\
\hline $\mathrm{Tf}-\mathrm{Hp}$ & 0.18 & 1.0 & $>3.5$ \\
\hline Ratio & - & 7.5 & - \\
\hline \multicolumn{4}{|c|}{ Concentration at $L D_{\operatorname{MAX}}(\mu \mathrm{M})$} \\
\hline $\mathrm{Hp}$ & 0.89 & 7.5 & 3.0 \\
\hline $\mathrm{Tf}-\mathrm{Hp}$ & 0.45 & 3.75 & 3.0 \\
\hline Ratio $^{\mathrm{a}}$ & 1.98 & 2.0 & 1.0 \\
\hline \multicolumn{4}{|c|}{ \% Cell cytotoxicity at $L D_{\operatorname{MAX}}$} \\
\hline $\mathrm{Hp}$ & 84 & 90 & 40 \\
\hline $\mathrm{Tf}-\mathrm{Hp}$ & 100 & 100 & 85 \\
\hline Ratio $^{\mathrm{a}}$ & 0.84 & 0.90 & 0.47 \\
\hline
\end{tabular}

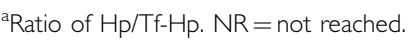

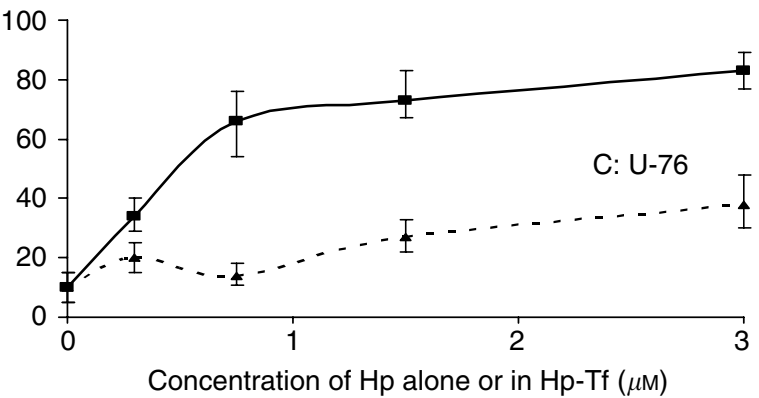

Figure 2 Dose-dependent cytotoxicity of $\mathrm{Hp}$ and $\mathrm{Tf}-\mathrm{Hp}$ for cells $\mathrm{FL}$ (A), K562 (B) and U-7.6 (C) cells. $0.5-1 \times 10^{5} \mathrm{cells} \mathrm{ml}^{-1}$ were cultured for $2 \mathrm{~h}$ in the dark in medium alone or containing Hp or Tf-Hp $(0-3 \mu \mathrm{M})$, washed, exposed to ambient fluorescent light for $16 \mathrm{~h}$ at room temperature and then recultured in full medium for $24 \mathrm{~h}$. Cell viability was assessed by trypan blue exclusion. The data represent the mean and standard deviation from at least three experiments.

used previously by us to study resistance to a ligand-Ricin A conjugate (Firer et al, 2003). Figure 5 shows the dose-response curve of FL cells exposed to a range of $\mathrm{Tf}-\mathrm{Hp}$ concentrations (first treatment). Those surviving the $\mathrm{LD}_{90}$ dose were passaged over several weeks in $\mathrm{Tf}-\mathrm{Hp}$-free medium and then retested for their dose-response to $\mathrm{Tf}-\mathrm{Hp}$ (second treatment). This process was repeated (third treatment). This protocol of repeated exposure did not result in the development of resistant cells as would be demonstrated by a shift to the right in the dose-response curve. Indeed, statistical analysis by ANOVA at different $\mathrm{Tf}-\mathrm{Hp}$ concentrations showed that repeated treatment of FL cells resulted in a statistically significant elevation in PDT sensitivity at $0.75 \mu \mathrm{g} \mathrm{ml}^{-1} \mathrm{Tf}-\mathrm{Hp} \quad(P<0.009)$ and at $1.5 \mu \mathrm{g} \mathrm{ml}^{-1} \mathrm{Tf}-\mathrm{Hp}$ $(P<0.012)$. At $3 \mu \mathrm{g} \mathrm{ml}^{-1} \mathrm{Tf}-\mathrm{Hp}$, there was no significant difference between the first, second or third treatments.

\section{Intracellular CL by luminol}

Experiments were performed to determine whether luminol is capable of inducing intracellular CL. Friend's leukaemia cells were incubated with a source of catalyst (ferrous sulphate) with or without luminol and CL measurements were made using a fluorescence spectrometer. Figure 6 shows that incubation of cells

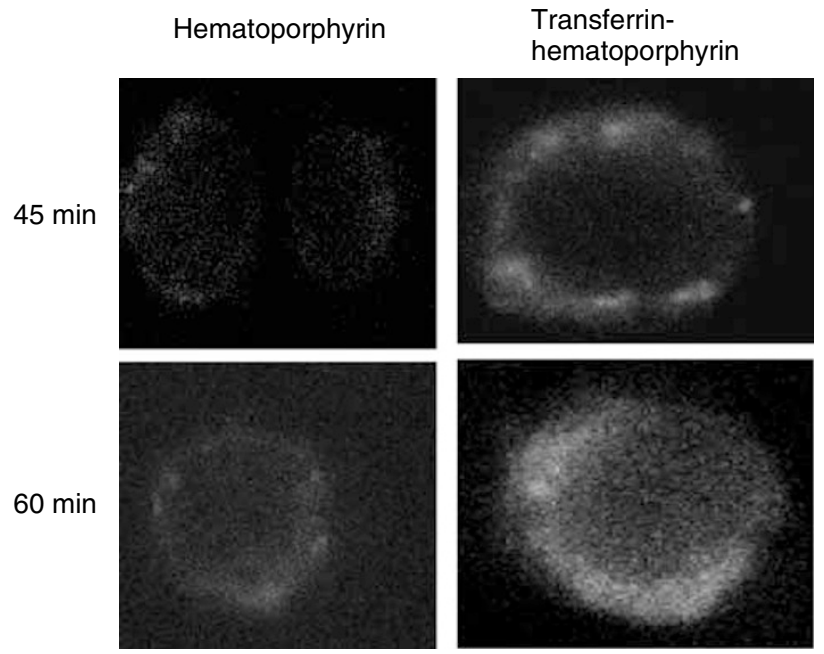

Figure 3 Fluorescent microscopy of $\mathrm{Hp}$ and $\mathrm{Tf}-\mathrm{Hp}$-treated $\mathrm{FL}$ cells. Cells were grown on glass slides in tissue culture dishes together with medium containing I $\mu \mathrm{M}$ of $\mathrm{Hp}$ or $\mathrm{Tf}-\mathrm{Hp}$ for 45 and $60 \mathrm{~min}$ and then examined for fluorescence emission. Hp was found in relatively low levels around the cytoplasmic membrane whereas $\mathrm{Tf}-\mathrm{Hp}$ was mainly internalised in intracellular vesicles.

with catalyst did produce notable CL over a 50 min incubation period. However, addition of luminol to the cell suspension resulted in measurable luminescence after about $20 \mathrm{~min}$ incubation that peaked after an additional $10 \mathrm{~min}$.

\section{Intracellular PDT activation of $\mathrm{Hp}$ or $\mathrm{Tf}-\mathrm{Hp}$ by luminol}

Despite the effective action of the Tf-Hp, PDT for leukemia would be limited in vivo by the restricted tissue penetration of candescent light. We therefore tested the possibility of generating an intracellular chemiluminescent light signal to induce PDT. Figure 7 illustrates the cytotoxicity induced in FL cells cultured in the dark with $\mathrm{Hp}$ or $\mathrm{Tf}-\mathrm{Hp}$ either alone or together with $10 \mu \mathrm{m}$ luminol as the chemiluminescent energy source. The cells were not exposed to ambient fluorescent light at any stage of the procedure. We found 


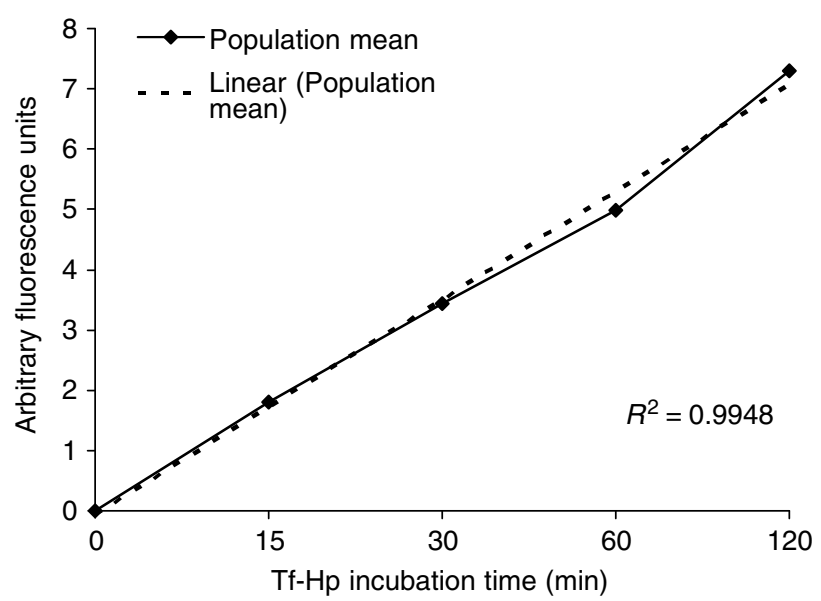

Figure 4 Kinetics of $\mathrm{Tf}-\mathrm{Hp}$ uptake into $\mathrm{FL}$ cells. 106 cells were incubated with $3 \mu \mathrm{g} \mathrm{Tf}-\mathrm{Hp}$ for the times indicated. Cells were washed three times with PBS and fluorescence measured by FACS. The figure depicts the increase in the mean arbitrary fluorescence units measured for the total cell sample measured (approx. 103 cells at each time period) vs incubation time. The least-squares linear regression line also shown.

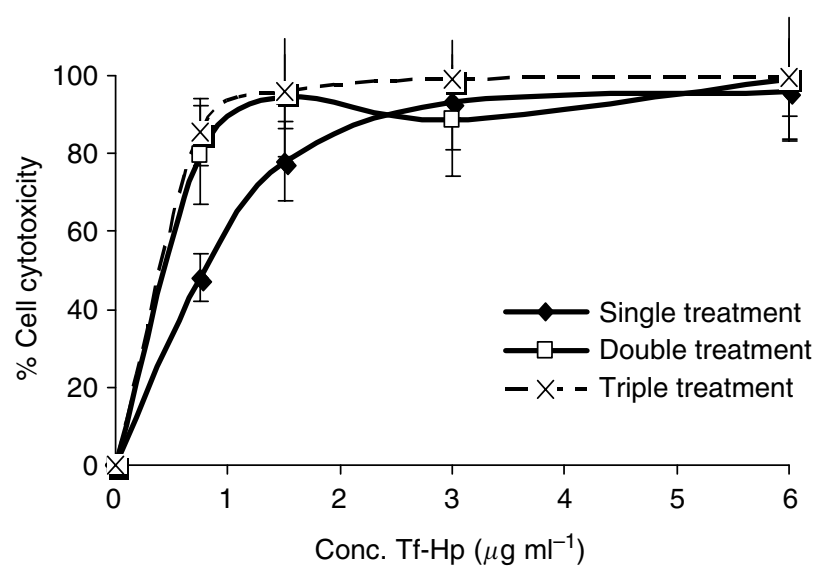

Figure 5 Repeated exposure to $\mathrm{Tf}-\mathrm{Hp}$ does not induce resistance in treated cells. Friend's leukaemia cells were treated with Tf-Hp for doseresponse (see Materials and Methods) $(\diamond)$. Cells surviving treatment at the $\mathrm{LD}_{90}$ concentration were cultured in $\mathrm{Tf}-\mathrm{Hp}$-free culture medium for approximately 3 weeks and then re-tested, together with fresh FL cells, for their dose-response to Tf-Hp challenge $(\boldsymbol{\square})$. Cells surviving this second treatment at the $\mathrm{LD}_{90}$ were processed through a third treatment cycle $(x)$. Cell viability was determined by trypan blue exclusion. Data points represent the mean \pm standard deviation of three experiments. Photodynamic therapy sensitivity of FL cells was significantly increased after repeated exposure to Tf-Hp at $0.75 \mu \mathrm{gml} \mathrm{m}^{-1} \mathrm{Tf}-\mathrm{Hp}(P<0.009)$ and at I.5 $\mu \mathrm{g} \mathrm{ml}^{-1} \mathrm{Tf}-\mathrm{Hp}(P<0.0 \mathrm{I} 2)$.

that (i) luminol alone induced about $15 \%$ cytotoxicity, (ii) $\mathrm{Hp}$ alone had little effect on cell viability, (iii) cytotoxicity reached a maximum of $30 \%$ in the presence of $\mathrm{Hp}$ and luminol and (iv) luminol induced a significant PDT effect upon addition of $\mathrm{Tf}-\mathrm{Hp}$ $(P=0.0043)$. Figure 8 further demonstrates that the cytotoxic luminol-induced PDT effect is dependent on the concentration of both $\mathrm{Tf}-\mathrm{Hp}$ and luminol with a combination of $10 \mu \mathrm{M}$ luminol and $3 \mu \mathrm{M}$ of conjugate producing maximum cytotoxicity. A reduction in Tf-Hp concentration had less effect on cytotoxicity than did diluting the level of luminol. We tested if synchrony in exposure to luminol and $\mathrm{Tf}-\mathrm{Hp}$ is a requirement for this cytotoxicity by incubating cells first with $\mathrm{Tf}-\mathrm{Hp}$, washing and then exposing them to luminol following various delay times. The time taken to wash the cells and return them to culture was approximately $15 \mathrm{~min}$.
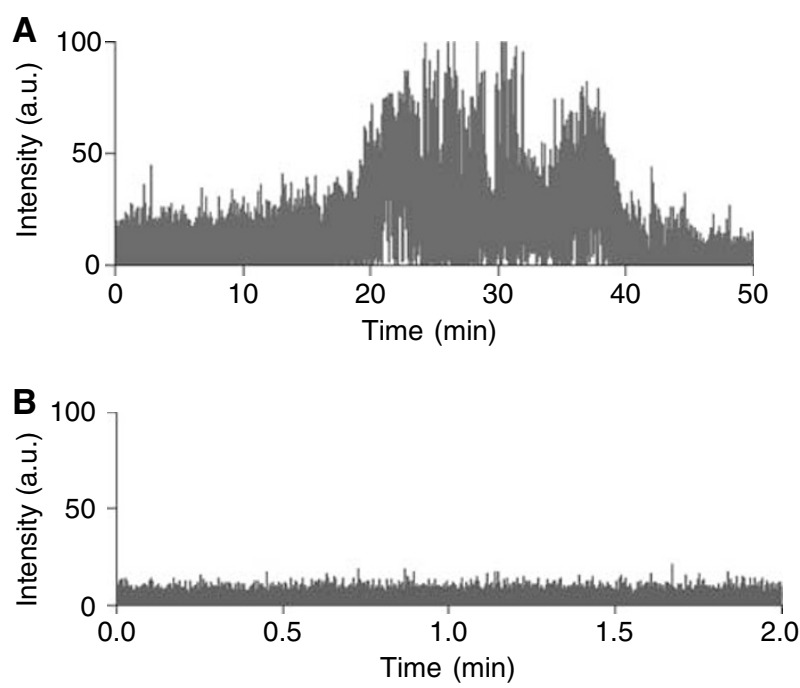

Figure 6 Intracellular CL in FL cells induced by luminol. Cells were suspended in LB buffer (see Materials and Methods) + I mM iron catalyst and used to measure background $\mathrm{CL}$ (graph $\mathbf{A}$ ) over a 50 min incubation period. A separate aliquot of cells were similarly suspended but together with I mM luminol (graph B). Measurements were made with a fluorescence spectrometer set to bio/CL mode and the readout was in arbitrary units.

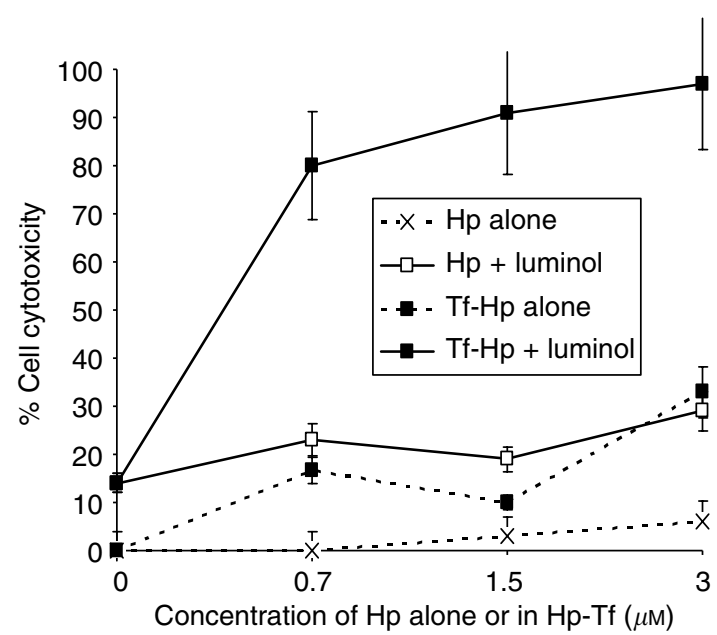

Figure 7 Molecular, intracellular activation of the PDT effect. FL cells were cultured in the dark for $48 \mathrm{~h}$ at $37^{\circ} \mathrm{C}$ with haematoporphyrin (Hp) or $\mathrm{Tf}-\mathrm{Hp}$ conjugate $(0-3 \mu \mathrm{M})$ together with $10 \mu \mathrm{M}$ luminol. No other manipulation or external radiation of the cells was performed. At the end of the culture period, cell viability was determined by trypan blue exclusion.

Although delaying the exposure to luminol by $30 \mathrm{~min}$ had no effect on the cytotoxicity (Figure 9A), after $60 \mathrm{~min}$ of delay, the PDT effect was reduced by $50 \%$. However by reversing the protocol (Figure 9B), we found that preincubation with luminol for $24 \mathrm{~h}$ sensitised the cells to the delayed exposure to Tf-Hp and the PDT effect was dose dependent. Washing or not washing the luminolincubated cells before their exposure to $\mathrm{Tf}-\mathrm{Hp}$ had no significant effect on the IAP activity.

\section{DISCUSSION}

This study addresses two aspects of PDT technology. The first concerns the development of PDT systems to enhance the 


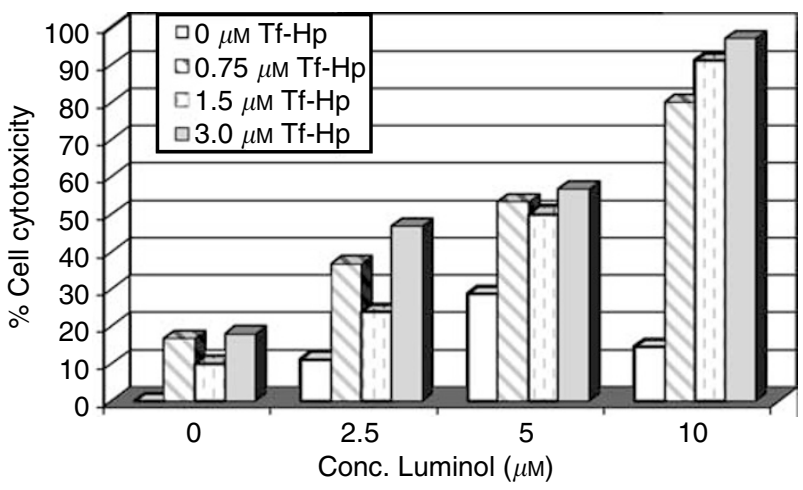

Figure 8 The effect of component concentration of the IAP. Friend's leukaemia cells were cultured in the dark for $48 \mathrm{~h}$ at $37^{\circ} \mathrm{C}$ with varying concentration combinations of $\mathrm{Tf}-\mathrm{Hp}$ conjugate $(0-3 \mu \mathrm{M})$ and luminol $(0-10 \mu \mathrm{M})$. No other manipulation or external radiation of the cells was performed. At the end of the culture period, cell viability was determined by trypan blue exclusion.

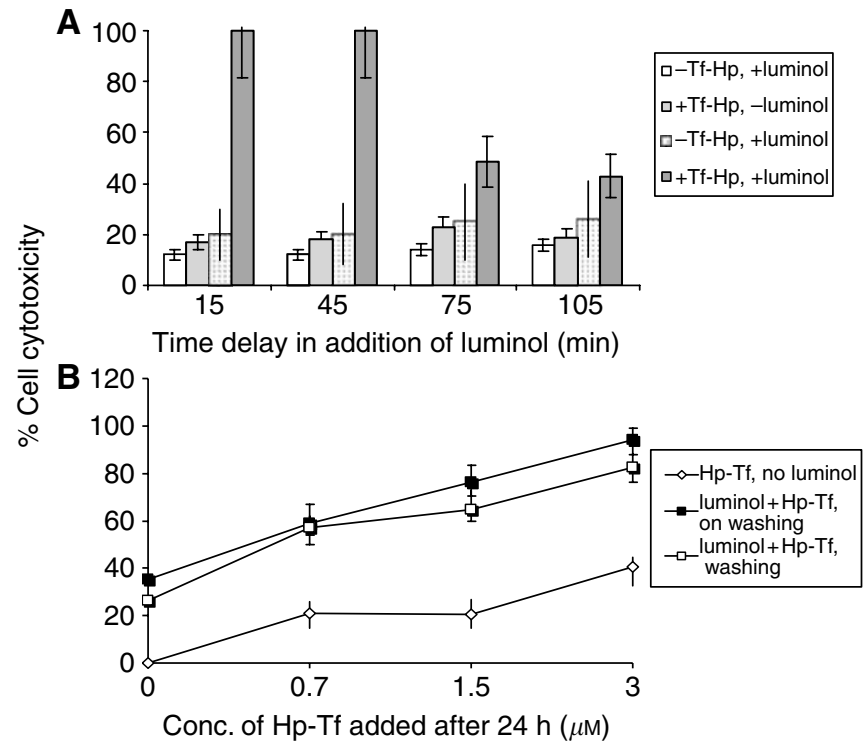

Figure 9 The molecular components for IAP need not be added in synchrony. (A) Effect of delayed PDT activation by luminol on cytotoxicity of $\mathrm{Tf}-\mathrm{Hp}$ treated FL cells. The cells were cultured for $2 \mathrm{~h}$ in the dark at $37^{\circ} \mathrm{C}$ with $\mathrm{Tf}-\mathrm{Hp}(3 \mu \mathrm{M})$ and washed. After various delay times $(0,30,60$ or $90 \mathrm{~min})$, luminol $(5 \mu \mathrm{M})$ was added and the cells were cultured for a further $16 \mathrm{~h}$ in the dark. The figure shows the \% of induced cytotoxicity. The 0 delay point includes time for washing of cells and returning them to the culture (approximately $15 \mathrm{~min}$ ). (B) Effect of pretreatment of FL cells by luminol on cell growth inhibition by Tf-Hp. The cells were first cultured for $24 \mathrm{~h}$ in the presence of $10 \mu \mathrm{M}$ luminol in the dark for $24 \mathrm{~h}$, washed or nonwashed and then cultured for a further $24 \mathrm{~h}$ in the presence of $\mathrm{Tf}-\mathrm{Hp}$ $(0-3 \mu \mathrm{M})$ at $37^{\circ} \mathrm{C}$

efficiency of delivery to target cells. Most (Hamblin and Newman, 1994; Klyashchitsky et al, 1994; Dolmans et al, 2003), but not all (Gijsens et al, 2002; Sharman et al, 2004) targeted PDT studies have used monoclonal antibodies as the address moiety. As the use of antibodies poses several practical limitations (Rihova, 1998), an alternate approach is to target a $\mathrm{Tf}-\mathrm{Ps}$ conjugate to $\mathrm{Tf}$ receptors that are overexpressed on tumour cells (Faulk et al, 1980; Cavanaugh, 2002). The therapeutic potential of $\mathrm{Tf}$-protein (Weaver and Laske, 2003) and Tf-chemical (Singh et al, 1998) toxin conjugates have already been examined, but less is known about $\mathrm{Tf}-\mathrm{Ps}$ conjugates particularly with regard to $\mathrm{Hp}$ which, although having been used successfully in free form in the clinic for over a decade (Dolmans et al, 2003; Brown et al, 2004), has been little tested in targeted PDT (Hamblin and Newman, 1994; Gijsens et al, 2002).

We prepared and characterised $\mathrm{Tf}-\mathrm{Hp}$ conjugates and found that these were at least six-fold more effective in inducing cell death at the $\mathrm{LD}_{50}$ level (Figure 2 and Table 1). High concentrations of Tf-Hp alone induced low-level cytotoxicity in accordance with previous reports (Supino et al, 1986; Luksiene and de Witte, 2003), an effect that may be related to the ability of $\mathrm{Hp}$ to inhibit the activity of protein kinase C (Luksiene and de Witte, 2003). However, there was variability among the cells in their sensitivity to PDT, with erythroleukemic cells showing between 3.5 and 19.4-fold greater sensitivity than hybridoma cells. We have seen a similar relative lack of PDT sensitivity in other hybridoma cells (data not shown) and, although we did not measure this parameter, we believe that it reflects the high TfR levels on erythroid cells. A similar pattern of sensitivity was also seen with free $\mathrm{Hp}$ treatment. Because in order to induce cytotoxicity $\mathrm{Hp}$ must interact with cell membrane lipids (Ehrenberg et al, 1985), the results suggest that the molecular makeup of the three cell membranes is different. This assumption is supported by earlier studies showing that variation in lipid bilayer components, in particular cholesterol and phosphatidylcholine, influences the binding and depth of penetration of $\mathrm{Hp}$ into cell membranes and liposomes (Lavi et al, 2002). Consideration should also be made as to the relative contributions of $\mathrm{Tf}$ and $\mathrm{Hp}$ to the overall contact between the conjugate and the cell membrane. We do not know the spatial orientation of the two components within the conjugate but the observation that in FL cells for example, a three-fold increase in cytotoxicity was obtained with $\mathrm{Tf}-\mathrm{Hp}$ as compared to free $\mathrm{Hp}$, suggests that the Tf makes a foremost contribution to the conjugate-membrane interaction and/or the effectiveness of its uptake.

Aside from increasing target specificity and efficiency, PDTinduced cell death is faster when $\mathrm{Tf}-\mathrm{Hp}$ is used. For example, during optimisation of the LTC cytotoxicity assay we noticed that whereas almost $100 \%$ cytotoxicity was achieved after only $30 \mathrm{~min}$ exposure to $\mathrm{Tf}-\mathrm{Hp}$, about $2 \mathrm{~h}$ were required for maximum activity $(24 \%)$ of free $\mathrm{Hp}$ (data not shown). Moreover, fluorescence microscopy of Hp and Tf-Hp-treated FL cells (Figure 3) demonstrated that $\mathrm{Tf}-\mathrm{Hp}$ is taken up more rapidly and that it reaches intracellular organelles and this would provide for more effective disruption of intracellular membranes. This is relevant in light of data demonstrating that ${ }^{1} \mathrm{O}_{2}$ molecules generated by Ps activation rapidly diffuse out of the cell surface bilayer (Lavi et al, 2002).

An important limitation of current chemotherapy is the frequent induction of multidrug resistance (MDR) in treated cells to a range of compounds that share apparently no structural or functional similarities (Hirose, 2002; Liscovitch and Lavie, 2002). Several cell surface transporter proteins have been identified as central components in this phenomenon (Gottesman et al, 2002). Interestingly, we (Firer et al, 2003) and others (Wang et al, 2000; Mazel et al, 2001) have shown that LTCs comprising protein toxins or DNA-damaging drugs seem to bypass the MDR transporters and do not to induce resistance. This is probably due to the pathway of cell entry that involves receptor-mediated endocytosis, initial passage of the LTC to lysosomes and then release of the toxin component to other intracellular targets, such as the endoplasmic reticulum and nucleus. With regards to PDT, whereas this modality has been found effective against MDR tumour cells (Capella and Capella, 2003; Preise et al, 2003), very few studies have directly approached the possibility of resistance developing to repeated Ps exposure. Madsen et al (2003) for instance reported that no resistance developed in glioma spheroids repeatedly exposed to free 5-aminoelulinic acid but as we have shown that LTCs are much more effective than free Ps we subjected FL cells to several rounds of treatment with suboptimal doses of $\mathrm{Tf}-\mathrm{Hp}$ (Figure 5). Our results support Madsen et al's conclusion that PDT 
does not induce the MDR phenomenon. This is in contrast to the well recognised resistance that FL cells develop to repeated exposure to other cytotoxins such as anthracyclines (Abbadessa et al, 1992; Desoize et al, 1994). From the fluorescence microscopy results (Figure 3), it may be postulated that LTC treatment concentrates the Ps in intracellular organelles that are not available to MDR transporters. The data from Figure 5 further indicate that FL cells surviving an initial LTC-PDT attack become more sensitive to subsequent treatments. At this point, we do not have an explanation for this phenomenon.

The second issue of PDT technology we addressed concerned the source of the luminescent activating signal delivered to the Ps. External radiation provides homogeneous excitation of Ps to cells in tissue culture or those injected subcutaneously; however, penetration of visible spectrum light waves into internal tissue is not uniform for all wavelengths (Moan and Peng, 2003) as after only a few millimeters, the cellular mass causes a dramatic drop in and scattering of transferred energy, precluding the use of PDT for deeper tissue targets (Ceburkov and Gollnick, 2000). Efforts to overcome this limitation have concentrated on new external light devices (Brancaleon and Moseley, 2002; Chen et al, 2002) or improved catheters. Our aim was to provide a molecular lightemitting mechanism within or at least proximal to the Ps-loaded target cell. This strategy is noninvasive, does not expose normal tissue to irradiation and a molecular illuminator could potentially be transported to any target cell in vivo. We use the term intracellular activation of PDT (IAP) to describe such molecular systems.

One CL activator is luminol, which undergoes a light-emitting process catalysed by metal ions and hydrogen peroxide (White et al, 1964; Weeks, 1992). This process is extensively employed in chemiluminescent detection techniques (Kricka, 2002; Templin et $a l, 2002$ ) and in cell physiology studies (Kubo et al, 1987; Nemeth et al, 1999; Kawagae and Nakagawa, 2000) but there is no literature on the use of luminol as an energy source in the field of PDT of cancer cells. The emission spectrum of luminol has been reported to comprise two major peaks, at 424 and $485 \mathrm{~nm}$ (White et al, 1964). We found that the first of these corresponds to a crest in the absorption spectrum of $\mathrm{Tf}-\mathrm{Hp}(412 \mathrm{~nm})$ but not to those of free $\mathrm{Hp}$ or Tf (375 and $280 \mathrm{~nm}$, respectively, Figure 1). This information, together with the enhanced intracellular uptake of the $\mathrm{Tf}-\mathrm{Hp}$ relative to $\mathrm{Hp}$ suggested to us that an IAP involving luminol might be effective for our system.

Firstly, we determined that luminol could indeed induce intracellular CL. Figure 6 demonstrates that after a period of incubation, cells exposed in the dark to luminol and an iron catalyst luminescence. This response was not of rapid onset that might reflect slow cellular uptake of luminol. In subsequent experiments, $\mathrm{Hp}$ or $\mathrm{Tf}-\mathrm{Hp}$ was mixed with luminol and added to FL cell culture in the dark (Figure 7). Not only was there a significant PDT effect when both $\mathrm{Tf}-\mathrm{Hp}$ and luminol were added to the cells, but the cytotoxic efficiency of $\mathrm{Tf}-\mathrm{Hp}$ over $\mathrm{Hp}$ was even more enhanced than that seen with the external light source (Figure 2). However, the concentration of $\mathrm{Tf}-\mathrm{Hp}$ required to attain $\mathrm{LD}_{\mathrm{MAX}}$ in the IAP system was 6.7 times higher than with external radiation (Figure 7 and Table 1). Luminol alone appeared to induce little cytotoxicity and these levels were similar to the PBS control (data not included in the figure). As this IAP system progresses to in vivo studies one important parameter to test will be the physiological effect, in any, of luminol. Little information is currently available on this issue, although a recent study by
Sanders et al (2000) demonstrated that the compound had no detrimental effect on rat metabolism.

Luminol-induced CL has been used in the past to study physiological parameters of phagocytic cells, as these produce the $\mathrm{H}_{2} \mathrm{O}_{2}$ needed for luminol oxidation (Nemeth et al, 1999; Dunn et al, 2005). But nonphagocytic cells, such as those used in this study, also possess several potential pathways through which to generate luminol-activating $\mathrm{H}_{2} \mathrm{O}_{2}$. These include a variety of signalling pathways (Finkel, 1998) and intracellular iron metabolism (Caltagirone et al, 2001). Also, reactive oxygen species such as $\mathrm{O}_{2}{ }^{*}$ produced in mitochondria by the electron transport chain are dismuted to $\mathrm{H}_{2} \mathrm{O}_{2}$ (Batandier et al, 2002), which diffuses into the cytoplasm (Antunes and Cadenas, 2000). Oxidant products of nitric oxide have also been shown to activate luminal (Catz et al, 1995).

Other IAP systems have also been studied. Carpenter et al (1994) described a bioluminescent mechanism for PDT that induced killing of virus-infected cells, involving the activation of hypericin following oxidation of luciferin by luciferase. They too reported that a continuous source of external radiation resulted in more effective target cell cytotoxicity and suggested that this may be related to suboptimal proximity between the luciferin and the hypericin. An alternate explanation based on the short half-life of the CL reaction itself $(\sim 1 \mathrm{~min})$ and rapid decrease in light emission intensity cannot be ruled out. Whatever the explanation, these limitations might be overcome by incorporating enhancer molecules into the IAP system to prolong and intensify the luminescent signal analogous to improvements made to the original chemiluminescent techniques (Kricka, 2000).

Additional experiments (Figure 9) demonstrated that the Ps and IAP systems need not be applied simultaneously in order to produce an effective PDT response. Delaying the addition of luminol (by up to $45 \mathrm{~min}$ ) to $\mathrm{Tf}-\mathrm{Hp}$-loaded cells, or delaying the addition of $\mathrm{Tf}-\mathrm{Hp}(24 \mathrm{~h})$ to luminol-loaded cells did not affect cytotoxicity. As the loaded cells were thoroughly washed before the exposure to luminol, these results reflect activation of the internalised $\mathrm{Tf}-\mathrm{Hp}$ or luminol rather than material loosely bound to the membrane.

In conclusion, our data demonstrate that $\mathrm{Tf}-\mathrm{Hp}$ conjugates represent an effective vehicle for PDT-induced cytotoxicity. Transferrin conjugates are being clinically tested against neurological tumours (Hall, 2000) and it remains to be seen whether the presence of Tf receptors on normal cells will preclude the use of Tf-Hp against haematological cancers (Hamblin and Newman, 1994; Brown et al, 2004). Experience with monoclonal antibodies against nontumour-specific antigens such as CD20 and EGFR (Tobinai, 2002; Goldberg, 2005) suggests that the enhanced expression of $\mathrm{TfR}$ on tumour cells and the targeting effect of $\mathrm{Tf}-\mathrm{Hp}$ may provide an effective therapeutic window. We are currently studying this with in vivo murine models. Finally, the ability to activate the PDT effect intracellularly without the need for external radiation opens the way for wider application of PDT technology, particularly where internal diseased tissues are the target.

\section{ACKNOWLEDGEMENTS}

We thank Dr Rina Arad-Yellin for her continual support of our work and for critically reading the manuscript. We would like to thank Mr S Weiss for performing the measurements of intracellular chemiluminescence. This work was supported in part by a departmental research grant.

\section{REFERENCES}

Abbadessa V, Tolemeo M, Luparello M, Perricone R, Cajozzo A, Dusonchet L, Candiloro V, Crosta L, Rausa L (1992) Selection of a new multidrug resistant cell line from Friend leukemia cells by short and cyclic exposures to high concentrations of daunorubicin. Heamatologica 77: $137-141$
Antunes F, Cadenas E (2000) Estimation of $\mathrm{H}_{2} \mathrm{O}_{2}$ gradients across biomembranes. FEBS Lett 475: $121-126$

Batandier C, Fontaine E, Keriel C, Leverve XM (2002) Determination of mitochondrial reactive oxygen species: methodological aspects. $J$ Cell Mol Med 6: $175-187$ 
Brancaleon L, Moseley H (2002) Laser and non-laser light sources for photodynamic therapy. Lasers Med Sci 17(3): 173-186

Brown SB, Brown EA, Walker I (2004) The present and future role of photodynamic therapy in cancer treatment. Lancet Oncol 5(8): 497-508

Caltagirone A, Weiss G, Pantopoulos K (2001) Modulation of cellular iron metabolism by hydrogen peroxide. J Biol Chem 276: 19738 - 19745

Capella MA, Capella LS (2003) A light in multidrug resistance: photodynamic treatment of multidrug-resistant tumors. J Biomed Sci 10(4): $361-366$

Carpenter S, Fehr MJ, Kraus GA, Petrich JW (1994) Chemiluminescent activation of the antiviral activity of hypericin: a molecular flashlight. Proc Natl Acad Sci USA 91(25): 12273 - 12277. 2002; 72(2): 117-130

Catz SD, Carreras MC, Poderoso JJ (1995) Nitric-oxide synthase inhibitors decrease human polymorphonuclear leukocyte luminol-dependent chemiluminescence. Free Radic Biol Med 19: $741-748$

Cavanaugh PG (2002) Synthesis of chlorin e6-transferrin and demonstration of its light-dependent in vitro breast cancer cell killing ability. Breast Cancer Res Treat 72: 117-130

Ceburkov O, Gollnick H (2000) Photodynamic therapy in dermatology. Eur J Dermatol 10(7): 568-575; discussion 76

Chen J, Keltner L, Christophersen J, Zheng F, Krouse M, Singhal A, Wang SS (2002) New technology for deep light distribution in tissue for phototherapy. Cancer J 8(2): 154-163

Desoize B, Broglio C, Gorisee MC, Briois F, Carpentier Y, Delvincourt C, Dufr J (1994) Characterization of four Friend leukemia cell sublines resistant to adriamycin. Anticancer Res 14: 995-1000

Dolmans DE, Fukumura D, Jain RK (2003) Photodynamic therapy for cancer. Nat Rev Cancer 3(5): 380 - 387

Dougherty TJ, Gomer CJ, Henderson BW, Jori G, Kessel D, Korbelik M, Moan J, Peng Q (1998) Photodynamic therapy. J Natl Cancer Inst 90(12): $889-905$

Dunn JS, Freed BM, Gustafson DL, Stringer KA (2005) Inhibition of human neutrophil reactive oxygen species production and p67phox translocation by cigarette smoke extract. Atherosclerosis 179(2): 261-267

Ehrenberg B, Malik Z, Nitzan Y (1985) Fluorescence spectral changes of hematoporphyrin derivative upon binding to lipid vesicles, Staphylococcus aureus and Escherichia coli cells. Photochem Photobiol 41(4): $429-435$

Faulk WP, Hsi BL, Stevens PJ (1980) Transferrin and transferrin receptors in carcinoma of the breast. Lancet 2(8191): 390-392

Finkel T (1998) Oxygen radicals and signaling. Curr Opin Cell Biol 10: $248-253$

Firer MA, Laptev R, Kasatkin I, Trombka D (2003) Specific destruction of hybridoma cells by antigen-toxin conjugates demonstrate an efficient strategy for targeted drug therapy in leukemias of the B cell lineage. Leuk Lymphoma 44(4): 681-689

Gijsens A, Derycke A, Missiaen L, De Vos D, Huwyler J, Eberle A, de Witte P (2002) Targeting of the photocytotoxic compound AlPcS4 to Hela cells by transferrin conjugated PEG-liposomes. Int J Cancer 101(1): 78-85

Goldberg RM (2005) Cetuximab. Nat Rev Drug Dicov May (Suppl): S10-S11

Gottesman MM, Fojo T, Bates SE (2002) Multidrug resistance in cancer: role of ATP-dependent transporters. Nat Rev, Cancer 2: 48 - 58

Hall WA (2000) Targeted toxin therapy for malignant astrocytoma. Neurosurgery 46(3): 544-551

Hamblin MR, Newman EL (1994) Photosensitizer targeting in photodynamic therapy. I. Conjugates of haematoporphyrin with albumin and transferrin. J Photochem Photobiol B 26(1): 45-56

Hirose M (2002) Biology and modulation of multidrug resistance (MDR) in hematological malignancies. Int J Hematol 76(Suppl 2): 206-211

Kawagoe M, Nakagawa K (2000) Attenuation of luminol-amplified chemiluminescent intensity and peroxidation in livers of quertin-fed mice. Toxicol Lett 114: 189-196

Klyashchitsky BA, Nechaeva IS, Ponomaryov GV (1994) Approaches to targeted photodynamic tumor therapy. J Controlled Release 29: 1-16

Kricka LJ (2000) Application of bioluminescence and chemiluminescence in biomedical sciences. Methods Enzymol 305: 333-345

Kricka LJ (2002) Stains, labels and detection strategies for nuclear acids assays. Ann Clin Biochem 39: 114-129

Kubo A, Sasada M, Nishimura T, Moriguchi T, Kakita T, Yamamoto K, Uchino H (1987) Oxygen radical generation by polymorphonuclear leucocytes of beige mice. Clin Exp Immunol 70(3): 658-663

Lavi A, Weitman H, Holmes RT, Smith KM, Ehrenberg B (2002) The depth of porphyrin in a membrane and the membrane's physical properties affect the photosensitizing efficiency. Biophys J 82(4): 2101-2110
Li H, Qian ZM (2002) Transferrin/transferrin receptor-mediated drug delivery. Med Res Rev 22(3): 225-250

Liscovitch M, Lavie Y (2002) Cancer multidrug resistance: a review of recent drug discovery research. IDrugs 5(4): 349-355

Luksiene Z, de Witte PA (2003) Hypericin as novel and promising photodynamic therapy tool: studies on intracellular accumulation capacity and growth inhibition efficiency. Medicina (Kaunas) 39(7): $677-682$

Madsen SJ, Sun C-H, Tromberg BJ, Hirschberg H (2003) Repetitive 5 -aminolevulinic acid-mediated photodynamic therapy on human glioma spheroids. J Neuro-Oncology 62: 243-250

Mazel M, Clair P, Rousselle C, Vidal P, Scherrmann JM, Mathieu D, Temsamani J (2001) Doxorubicin-peptide conjugates overcome multidrug resistance. Anticancer Drugs 12(2): 107-116

Moan J, Peng Q (2003) An outline of the hundred-year history of PDT. Anticancer Res 23(5A): $3591-3600$

Mrsny RJ (2004) Strategies for targeting protein therapeutics to selected tissues and cells. Expert Opin Biol Ther 4(1): 65-73

Nemeth A, Jakus J, Kriska T, Keszler A, Vanyur R, Gal D (1999) Physicochemical modeling of the role of free radicals in photodynamic therapy. IV. Quantitative aspects of photodynamic effects on free radicals generated in cell cultures. Biochem Biophys Res Commun 255(2): $360-366$

Phillip MJ, Maximuke PP (1989) Chemiluminescence and hematoporphyrin derivative: a novel therapy for mammary adenocarcinomas in mice. Oncology 46(4): 266-272

Ponka P, Beaumont C, Richardson DR (1998) Function and regulation of transferrin and ferritin. Semin Hematol 35(1): 35-54

Preise D, Mazor O, Koudinova N, Liscovitch M, Scherz A, Salomon Y (2003) Bypass of tumor drug resistance by antivascular therapy. Neoplasia 5(6): $475-480$

Rihova B (1998) Receptor-mediated targeted drug or toxin delivery. $A d v$ Drug Deliv Rev 29(3): 273-289

Rittenhouse-Diakun K, Van Leengoed H, Morgan J, Hryhorenko E, Paszkiewicz G, Whitaker JE, Oseroff AR (1995) The role of transferrin receptor (CD71) in photodynamic therapy of activated and malignant lymphocytes using the heme precursor delta-aminolevulinic acid (ALA). Photochem Photobiol 61(5): 523-528

Sanders JM, Chen L-J, Burka LT, Matthews HB (2000) Metabolism and deposition of luminol in the rat. Xenobiotica 30: 263-272

Shadidi M, Sioud M (2003) Selective targeting of cancer cells using synthetic peptides. Drug Resist Update 6(6): 363-371

Sharman WM, van Lier JE, Allen CM (2004) Targeted photodynamic therapy via receptor mediated delivery systems. Adv Drug Deliv Rev 56(1): $53-76$

Singh M, Atwal H, Micetich R (1998) Transferrin directed delivery of adriamycin to human cells. Anticancer Res 18(3A): 1423-1427

Stockfleth E, Sterry W (2002) New treatment modalities for basal cell carcinoma. Recent Results Cancer Res 160: 259-268

Supino R, Della Torre G, Ramponi R, Bottiroli G (1986) Effects of hematoporphyrin-derivative on mouse erythroleukemia cells in the absence of light irradiation. Chem Biol Interact 57(3): 285-294

Templin MF, Stoll D, Schrenk M, Traub PC, Vohringer CF, Joos TO (2002) Protein microarray technology. Drug Discov Today 7(15): 815-822

Tobinai K (2002) Rituzimab and other emerging monoclonal antibody therapies for lymphoma. Expert Opin Emerg Drugs 7(2): $289-302$

van Duijnhoven FH, Aalbers RI, Rovers JP, Terpstra OT, Kuppen PJ (2003) The immunological consequences of photodynamic treatment of cancer, a literature review. Immunobiology 207(2): 105-113

Vrouenraets MB, Visser GW, Snow GB, van Dongen GA (2003) Basic principles, applications in oncology and improved selectivity of photodynamic therapy. Anticancer Res 23(1B): 505-522

Wang F, Jiang X, Yang DC, Elliott RL, Head JF (2000) Doxorubicingallium - transferrin conjugate overcomes multidrug resistance: evidence for drug accumulation in the nucleus of drug resistant MCF-7/ADR cells. Anticancer Res 20(2A): 799-808

Weaver M, Laske DW (2003) Transferrin receptor ligand-targeted toxin conjugate (Tf-CRM107) for therapy of malignant gliomas. J Neurooncol 65(1): $3-13$

Weeks I (1992) Chemiluminescence immunoassay. In Wilson and Wilsons Comprehensive Analytical Chemistry Svehla G (ed), Vol. 29, pp 20-25. Elsevier Publishing Co.: London

White EH, Zafiriou O, Kagi HH, Hill JHM (1964) Chemiluminescence of luminol: the chemical reaction. I Am Chem Soc 86: 940-941 